${ }^{4}$ Warsaw University of Life Sciences - SGGW

\title{
Legal Regulations and the Perspectives of Renewable Energy Policy in Selected EU Member States
}

\begin{abstract}
The main objective of the paper is an evaluation of the development of the use of the RES in V4 countries compared to the EU-28 average and assessment, if national strategic goals regarding the share of the RES on gross inland energy consumption are achievable till 2020. To achieve the main aim of the paper it was decided to apply Brown triple exponential smoothing model as a main research method. Based on gathered results and using the extrapolation for making the forecast till do 2020 it was found out, that Slovakia might track the national target with point estimation of $16.25 \%$ (90\% CI: 13.98:18.53), Czech Republic 12.75\% (90\% CI: 10.44:15.06), Poland 19.9\% (90\% CI: 16.42: 23.37). In case of Hungary, it might fail to reach the national target with point estimation of $10.42 \%(90 \% \mathrm{CI}: 8.87: 11.98)$ and overall EU in average will not be able to reach common target with point estimation of $15.94 \%(90 \% \mathrm{CI}: 13.08: 18.8)$.
\end{abstract}

Key words: Energetics, EU energy policy, renewable energy policy, national targets, primarysecondary legislation

JEL Classification: Q28

\section{Introduction}

One of the biggest challenges of the energy sector, as well as one of the priorities of the EU, nowadays is to provide energy supply in a sustainable and eco-friendly way in the long-term perspective. In order to assure sustainability and durability of our energy sources and keeping in mind the environmental impact of energy production, it is necessary to divert our interest from energy sources that will eventually be depleted (such as fossil fuels) and concentrate on renewable energy sources (RES).

Policies supporting renewable energy sources (RES) have become a cornerstone of climate and energy policy in the EU. All EU Member States have introduced some form of RES support or a mix of support policies. Legislation in the field is based on The Lisbon treaty, being in force since 2009, which has for the first time granted the EU Commission explicit competencies in energy policy (Article 194 TFEU; Strunz, Gawel, Lehmann, 2016).

On 23 April 2009 the EU adopted The Directive 2009/28/EC on the promotion of the use of energy from renewable sources. The directive implements the so called 20/20/20 targets, mainly by setting sets national binding targets for all EU countries with the overall aim of making renewable energy sources account by 2020 for $20 \%$ of EU energy and for

\footnotetext{
${ }^{1}$ prof. JUDr., PhD., Faculty of European Studies and Regional Development Slovak University of Agriculture in Nitra, address: Tr. A. Hlinku 2, 94976 Nitra, Slovakia; e-mail: eleonora.marisova@uniag.sk,

${ }^{2}$ Ing., PhD, e-mail: martin.maris@uniag.sk

${ }^{3}$ Mgr., e-mail: jankogadus@pobox.sk

${ }^{4}$ PdD, Department of Finance, Faculty of Economic Sciences, WULS-SGGW, ul. Nowoursynowska 166 ,

02-787 Warszawa, e-mail: e-mail: agnieszka_parlinska@sggw.pl; https://orcid.org/0000-0001-6640-3097
} 
$10 \%$ of energy specifically in the transport sector (Proskurina, Sikkema, Heinimö, Vakkilainen, 2016).

The primary legal source on RES in the Czech Republic is Act No. 165/2012 Coll. on promoted energy sources. Other legal sources in the Czech Republic regarding RES are: Act No. 353/2003 Coll. on Consumption Taxes, which regulates the taxation of mineral oils, alcohol and tobacco with consumption taxes; 201/2012, Clean Air Act, which is in conjunction with Regulation No. 133/2010 Coll. on the Quality and Registration of Fuels sets obligations for fuel producers, and Act No. 338/1992 Coll. on the Property Tax, by which constructions used for renewable heating plants are exempt from property tax.

By secondary legislation on RES in the Czech Republic are covered subsidies, e. g. Operational Program "Business and Innovation for Competitiveness" 2014-2020, Operational Program Environment 2014-2020 and Directive of the Ministry of Environment No. 6/2014 on the submission of applications and the allocation of grants for projects under the Operational Program Environment.

Hungary is the only country of V4 countries, which does not have a primary legal source on RES and the field of RES is mainly regulated by secondary legislation. Some fields of RES are regulated by Act No. LXXXVI of 2007 on the Electric Energy, Act No. CXVII of 2010 on the promotion of renewable energy in the transport sector, and the reduction of greenhouse gases in the transport sector; CXXVII of 2003 on the excise duty and the rules on excise good sales.

The secondary legislation on RES is the following: Government Decree No. 389/2007 (XII.23.). On the compulsory dispatch and purchase of electricity generated from waste or from renewable energy sources, Governmental Decree no. 309/2013 (VIII.16.). On the certification of origin for electricity from renewable energy sources and the high efficiency combined heat and power, Government Decree No. 273/2007 (X. 19) on the Implementation of Act No. LXXXVI of 2007 on Electric Energy - Regulations for household-sized power plants $<50 \mathrm{kV}$ (HMKE), Decree of the Hungarian Energy and Public Utility Regulatory Authority No. 4/2013 (X.16.) On the Application of Grid Use Charges, Distribution Regulation on the Access to the Distribution Grid of 10.12.2013, Decree of the Hungarian Energy and Public Utility Regulatory Authority No. 7/2014 (Dec. 12) on the Determination, Amount and Adjustment of Fees for Connection to the Public Electricity Network, Decree No. 63/2013 (X.29.) NFM on the distribution of electricity subject to feed-in obligations by the transmission system operator and on the methodology of determining prices to be applied in the course of distribution, Government Decision No. 1318/2015 (V.21.). On the Budget for 2015 of the Environment and Energy Efficiency Operational Program, Governmental Decision No. 1811/2015 (XI.10) on the Budget for 2015 of the Territorial and Settlement Development Operational Program, Decree No. 391/2015 (XII 11) on the amendment of certain governmental decrees on energy, Government Decision No. 1318/2015 (V. 21) on the Budget for 2015 of the Environment and Energy Efficiency Program, Governmental Decision No. 1811/2015 (XI.10) on the Budget for 2015 of the Territorial and Settlement Development Operational Program and Government Decree No. 343/2010 (XII.2008) on the conditions and certification of sustainable biofuel production. 
Table 1. Support schemes in V4 countries

\begin{tabular}{|c|c|c|}
\hline & & Support schemes \\
\hline \multirow{3}{*}{$\mathrm{CZ}$} & $\mathrm{H} \& \mathrm{C}$ & $\begin{array}{l}\text { Is mainly supported through subsidies. Furthermore, renewable heating plants are exempt from } \\
\text { real estate tax. }\end{array}$ \\
\hline & E & $\begin{array}{l}\text { In the Czech Republic, renewable energy is supported through either a guaranteed feed-in tariff } \\
\text { or a green bonus paid on top of the market price. }\end{array}$ \\
\hline & $\mathrm{T}$ & $\begin{array}{l}\text { Main support scheme for renewable energy sources used in transport is a quota system. } \\
\text { Furthermore, biofuels are exempt from consumption tax. }\end{array}$ \\
\hline \multirow{3}{*}{$\mathrm{HU}$} & $\mathrm{H} \& \mathrm{C}$ & Support is currently provided by subsidy programmes. \\
\hline & $\mathrm{E}$ & $\begin{array}{l}\text { Hungary promotes renewable electricity through feed-in tariffs, green premium I, green } \\
\text { premium II (tender), net metering and subsidy programmes. }\end{array}$ \\
\hline & $\mathrm{T}$ & $\begin{array}{l}\text { The main support scheme for the promotion is a quota system. Further, a tax reimbursement } \\
\text { applies to certain biofuels in case of engine development projects and vehicles used in the } \\
\text { mining industry and in water management. Also certain subsidy programmes are applicable. }\end{array}$ \\
\hline \multirow{3}{*}{ PL } & $\mathrm{H} \& \mathrm{C}$ & $\begin{array}{l}\text { Is supported through subsidies schemes (state-owned bank and the National Fund for } \\
\text { Environmental Protection and Water Management) and loans (the National Fund for } \\
\text { Environmental Protection and Water Management). }\end{array}$ \\
\hline & $\mathrm{E}$ & $\begin{array}{l}\text { Is promoted through support schemes, which includes tenders (feed-in tariffs and premiums), } \\
\text { subsidies and loans from National Fund for Environmental Protection and Water Management, } \\
\text { support scheme for prosumers and tax regulation mechanism (exempt from the tax on the sale } \\
\text { and consumption of electricity). }\end{array}$ \\
\hline & $\mathrm{T}$ & Is promoted through a biofuels quota obligation. \\
\hline \multirow{3}{*}{ SK } & $\mathrm{H} \& \mathrm{C}$ & Is promoted through subsidies (Operational Programme Quality of Environment). \\
\hline & $\mathrm{E}$ & $\begin{array}{l}\text { Mainly promoted through feed-in tariffs. In addition, is also supported through subsidies } \\
\text { (Operational Programme Quality of Environment) and tax regulation mechanisms (exemption } \\
\text { from excise tax). }\end{array}$ \\
\hline & $\mathrm{T}$ & $\begin{array}{l}\text { The main support scheme for renewable energy sources used in transport is a quota system. } \\
\text { Furthermore, biofuels are supported through a tax regulation mechanism (lower mineral oil tax } \\
\text { or exempt from this tax). }\end{array}$ \\
\hline
\end{tabular}

Shortcuts: CZ - the Czech Republic, HU - Hungary, PL - Poland, SK - Slovakia, H\&C - Heating and Cooling, E Electricity Generation, $\mathrm{T}$ - Transport

Source: Own processing based on RES LEGAL Europe - legal sources on renewable energy, available at: http://www.res-legal.eu/compare-support-schemes/.

In Poland, the main legal source for RES is Act of 20.02.2015 on renewable energy sources, which has been in force only from 01.01.2016. The support of RES can also be found in other laws, such as the Act of 10.04.1997, Energy Law, which also applies to renewable electricity generation, Act of 27 April 2001 on environmental protection, which provides rules on the granting of loans, Act of 25.08.2006 on Biocomponents and Liquid Biofuels, which sets out rules for the production and trade of biocomponents and liquid biofuels.

Secondary legislation in Poland covers, in particular, the quota system, subsidies and national targets, for example Order of 18.10.2012, the Priority Program RES (Stork) and the Regulation of 23 July 2013 on the National Indicative Targets for 2013-2018.

Slovakia, as well as Poland and Czech Republic, has the main act covering RES that is Act No. 309/2009 Coll. on the Support of Renewable Energy Sources. Beside this act, RES are regulated in Act No. 609/2007 Coll. on the Excise Tax, in which are set tax support mechanisms of RES, in Act No. 98/2004 Coll. on excise duties on mineral oil, in which are 
set tax support mechanisms of RES and quota system, and in Act No. 555/2005 Coll. on Energy Performance of Buildings.

Secondary legislation on RES in Slovakia is settled in Decree No. 133/2012 Coll. On regulating the training and certification of installers, in Regulation No. 221/2013 Coll. of the regulatory authority, which sets the prices for energy, and in Operational Programme Environmental Quality for 2014-2020, which establishes a framework for the implementation of the measures of the Operational Programme Environmental Quality (RES LEGAL...).

The European Union is one of the largest energy consumers, as well as one of the largest greenhouse gas (GHG) emitters in the world, which calls for a common strategy in the energy sector. The Europe 2020 is the key strategy of the EU aiming at enhancing the economic growth of the EU over the years 2010-2020. This strategy involved energy and climate policy including the already mentioned so called 20/20/20 targets, namely reduction of greenhouse gas emissions (by 20\%), the increase of RES share (to 20\%) and the increase of energy efficiency, thus, saving up to $20 \%$ in the energy consumption (Genovaite, Butkus). The strategy 2020 was preceded by Communication "An Energy Policy for Europe", which outlines developments in the energy sector by 2010 as well as the 2020 targets. Subsequently, in March 2007, the European Council adopted the Energy Action Plan 2007-2010, which is an important element of climate change commitments:

- reducing greenhouse gas emissions by $20 \%$ by 2020 compared to 1990 ,

- increasing the share of renewable energy sources to $20 \%$ by 2020 ,

- achieving a share of $10 \%$ of renewable energy in transport by 2020 ,

- gaining $20 \%$ energy savings compared to projection by 2020 (The Energy..., 2014).

The Directive 2009/28/EC set mandatory national RES targets for Member states. Taking into consideration the RES potential of each Member State and respecting its energy mix, it was decided that the goal could vary, apart from the $10 \%$ for transport that was set as an equal target for all. According to the Directive, each Member State would have to adopt a national RE Action Plan, including national targets for the share of RES consumed in transport, electricity, heating and cooling until 2020, notifying their national RE Action Plans to the Commission by 30 June 2010 (Giacomarra, Bono). Most of the Member states are on the track to meeting, their RES criteria set out by their national plans (Klessmann), and almost half of the Member States (Austria, Bulgaria, Czech Republic, Denmark, Germany, Greece, Spain, France, Lithuania, Malta, Netherlands, Slovenia and Sweden) even planned to exceed their own targets (Genovaite, Butkus). The 2020 targets vary from $10 \%$ for Malta up to $49 \%$ for Sweden (Klessmann). According to Eurostat, the leaders in RES share are Sweden (53,9\%), Finland (39,3\%) and Latvia (37,6\%).

Further reaching goals are being outlined in the 2030 Energy Strategy, which elaborates on the 2020 goals. EU countries have agreed on a new 2030 Framework for climate and energy, including EU-wide targets and policy objectives for the period between 2020 and 2030. These targets aim to help the EU achieve a more competitive, secure and sustainable energy system and to meet its long-term 2050 greenhouse gas reductions target. Targets for 2030 are:

- a $40 \%$ cut in greenhouse gas emissions compared to 1990 levels,

- at least a $27 \%$ share of renewable energy consumption,

- at least $27 \%$ energy savings compared with the business-as-usual scenario (A policy..., 2014). 
However, the application of the energy policies is subject to a high degree of uncertainty. The origin of this lies in the insecurity associated with the anticipated technological development, the evolution of the economic situation, possible changes in the regulatory framework, the evolution of the factors that impact the final price of the policies to be implemented, and the efficacy of compliance with the environmental objectives that have been set. All of these circumstances clearly complicate decision making (de LlanoPaz, Martínez Fernandez, Soares, 2016).

\section{Material and methods}

The main aim of the paper is an evaluation of the development of the use of the RES in V4 countries compared to the EU-28 average and assessment, if national strategic goals regarding the share of the RES on gross inland energy consumption5 are achievable till 2020. For this purpose we decided to use Brown triple exponential smoothing model in estimating of the point forecast ex ante, determined in time $t=T$ for time $t+h$ for $\mathrm{h}=1,2, \ldots, \mathrm{H}$. As a underlying variable we choose an evaluation of the development of the use of the RES in V4 countries compared to the EU-28 average.

The research sample consists of time series-data about the share of the RES of gross inland energy consumption in percentage for V4 countries in the respective time period $1990-2015$, thus $\mathrm{N}=26$, with prognosis until 2020. The development of the share of the RES gross inland energy consumption, we compare with the EU-28 average. Furthermore, we make a short-term forecast of the RES share till 2020 in the case of the V4 countries and also for the EU-28 average via using statistical extrapolation methods. The time-series data are obtained from Eurostat.

After consideration of various methods of extrapolation (Hamilton, 1994; Rublíková, 2007) we have opted for Brown triple exponential smoothing model. For our research we use the second order polynomial (quadratic trend). We use adaptive estimation of the three parameters of local quadratic trends in time $t$, generally defined:

$$
y_{t}=\beta_{0}+\beta_{1} t+\frac{1}{2} \beta_{2} t^{2}+\varepsilon_{t}
$$

Furthermore, triple exponential smoothing is derived from the use of three exponential averages:

$$
\begin{gathered}
\mathrm{S}_{\mathrm{t}}=\alpha \mathrm{y}_{\mathrm{t}}+(1-\alpha) \mathrm{S}_{\mathrm{t}-1} \\
\mathrm{~S}_{\mathrm{t}}^{(2)}=\alpha \mathrm{S}_{\mathrm{t}}+(1-\alpha) \mathrm{S}_{\mathrm{t}-1}^{(2)} \\
\mathrm{S}_{\mathrm{t}}^{(3)}=\alpha \mathrm{S}_{\mathrm{t}}+(1-\alpha) \mathrm{S}_{\mathrm{t}-1}^{(3)}
\end{gathered}
$$

\footnotetext{
${ }^{5}$ Note: Gross inland energy consumption, sometimes abbreviated as gross inland consumption, is the total energy demand of a country or region. It represents the quantity of energy necessary to satisfy inland consumption of the geographical entity under consideration.
} 
Each parameter we estimate by use the:

$$
\begin{gathered}
\hat{\beta}_{0, \mathrm{t}}=3 \mathrm{~S}_{\mathrm{t}}-3 \mathrm{~S}_{\mathrm{t}}^{(2)}+\mathrm{S}_{\mathrm{t}}^{(3)} \\
\hat{\beta}_{1, \mathrm{t}}=\frac{\alpha}{2(1-\alpha)^{2}}\left[(6-5 \alpha) \mathrm{S}_{\mathrm{t}}-(10-8 \alpha) \mathrm{S}_{\mathrm{t}}^{(2)}+(4-3 \alpha) \mathrm{S}_{\mathrm{t}}^{(3)}\right] \\
\widehat{\beta}_{2, \mathrm{t}}=\frac{\alpha^{2}}{(1-\alpha)^{2}}\left(\mathrm{~S}_{\mathrm{t}}-2 \mathrm{~S}_{\mathrm{t}}^{(2)}+\mathrm{S}_{\mathrm{t}}^{(3)}\right.
\end{gathered}
$$

Where $\alpha \in\langle 0 ; 1\rangle$ is smoothed constant.

Next we make the point estimation of the forecast ex ante for time $t=\mathrm{T}$ on time $\mathrm{t}=\mathrm{T}+\mathrm{h}$ for $\mathrm{h}=1,2, \ldots, \mathrm{H}$ :

$$
\hat{\mathrm{Y}}_{\mathrm{T}+\mathrm{h}}=\widehat{\beta}_{0, \mathrm{~T}}+\mathrm{h} \widehat{\beta}_{1, \mathrm{~T}}+\frac{1}{2} \mathrm{~h}^{2} \widehat{\beta}_{2, \mathrm{~T}}
$$

It is necessary to note, that the model is able to determine the value of the RES with highest confidence only one period ex ante and we can only try to determine it till 2020 with very low probability. This case is valid for all V4 countries and EU-28 average.

Next, the crucial issue is to determine the constant of $\alpha$. According the literature, under the subjective choice we should apply the rule: if slope parameter of the time series is unstable (higher variability), than $\alpha \rightarrow 1$, if the time series is stable (lower variability) we should choose "lower" level of $\alpha$ (Rublíková, 2007).

Further we should determine the confidence interval for $\mathrm{y}_{\mathrm{T}+\mathrm{h}}$ on (Bowerman, O'Connel, 2007):

$$
\hat{\mathrm{Y}}_{\mathrm{T}+\mathrm{h}}(\mathrm{T}) \pm \mathrm{z}_{1-\frac{\alpha}{2}} * \mathrm{~d}_{\mathrm{h}} * \mathrm{MAE}_{\mathrm{T}}
$$

Where $\hat{\mathrm{y}}_{\mathrm{T}+\mathrm{h}}(\mathrm{T})=\widehat{\beta}_{0, \mathrm{~T}}+\mathrm{h} \hat{\beta}_{1, \mathrm{~T}}+\frac{1}{2} \mathrm{~h}^{2} \widehat{\beta}_{2, \mathrm{~T}}$ is point estimation in the time $\mathrm{t}=\mathrm{T}$ for time $\mathrm{t}=\mathrm{T}+\mathrm{h} ; \mathrm{z}_{1-\frac{\alpha}{2}}$ is \% quantil of the normal distribution $\mathrm{N}(0 ; 1), \mathrm{d}_{\mathrm{h}}$ we compute following:

$$
\begin{gathered}
\mathrm{d}_{\mathrm{h}}=1.25 * \sqrt{\frac{1+\frac{1-\alpha}{(1+\alpha)^{3}}\left[\left(1+4 \alpha+5 \alpha^{2}\right)+2(1-\alpha)(1+3 \alpha) \mathrm{h}+2(1-\alpha)^{2} \mathrm{~h}^{2}\right]}{1+\frac{1-\alpha}{(1+\alpha)^{3}}\left[\left(1+4 \alpha+5 \alpha^{2}\right)+2(1-\alpha)(1+3 \alpha)+2(1-\alpha)^{2}\right]}} \\
\operatorname{MAE}_{\mathrm{T}}=\sum_{\mathrm{t}=1}^{\mathrm{T}} \frac{\left|\mathrm{yt}_{\mathrm{t}}-\widehat{\mathrm{y}}_{\mathrm{t}}(\mathrm{t}-1)\right|}{\mathrm{T}}
\end{gathered}
$$

Finally we verify the practical convenience of the model via using the Theil decomposition of the mean square error (MSE) as following:

$$
\operatorname{MSE}=(\hat{y}-\bar{y})^{2}+\left(s_{\widehat{y}}-r s_{y}\right)^{2}+\left(1-r^{2}\right) s_{y}^{2}
$$

For interpretation purpose we divide both sides of the equation of the MSE: 


$$
1=\frac{(\hat{y}-\bar{y})^{2}}{M S E}+\frac{\left(s_{\hat{y}}-r s_{y}\right)^{2}}{M S E}+\frac{\left(1-r^{2}\right) s_{y}^{2}}{M S E}=U_{m}+U_{R}+U_{D}
$$

Where $U_{m}$ measures the part of the MSE error caused by the distortion of the reality by the model itself. $U_{R}$ measures part of the MSE error caused by the deviation of population regression function between the values $y$ and $\hat{y} . U_{D}$ is the result of imperfect correlation between the $y$ and $\hat{y}$, thus it is the error with non-systematic nature (Rublíková, 2007).

For ideal forecasting model it is valid: $U_{m}=0, U_{R}=0, U_{D}=1$.

\section{Results and Discussion}

For filling the objective of the paper, we opted for Brown triple exponential smoothing model as a main research method. For extrapolation the trend till 2020, we have used second order polynomial.

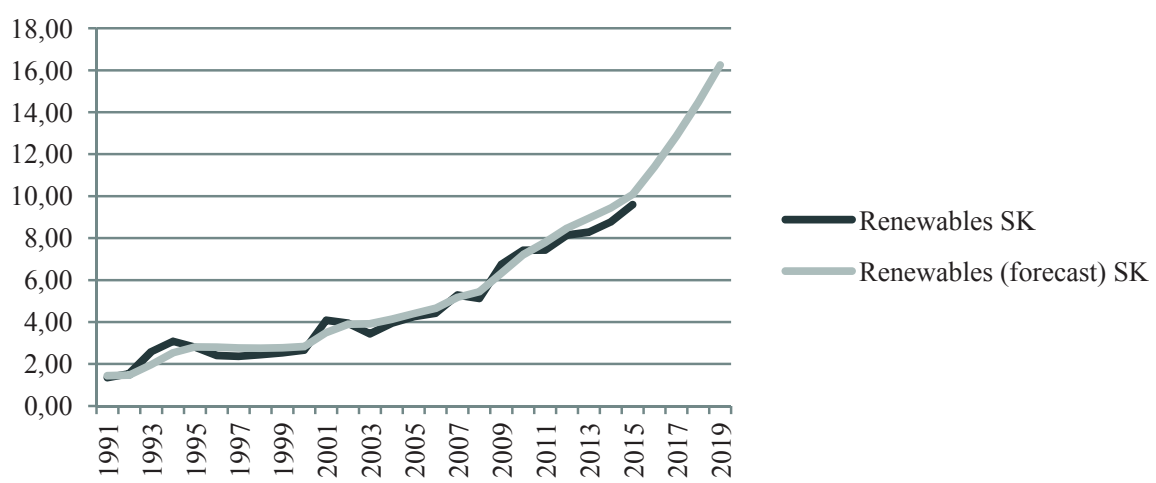

Fig. 1. Extrapolation of the contribution's trend of the RES on gross inland energy consumption in Slovakia in \% Sources: Own processing, based on Eurostat data, 2017.

In Figure 1 we can observe the potential development of the RES on gross inland energy consumption till 2020 in Slovakia. We can observe the steady rising trend since 2004 and there are good perspectives of achieving national target of reaching or evenly exceeding 14\% of the share of RES on energy consumption till 2020.

Table 2. Forecast ex ante for the share of the RES on gross inland energy consumption in Slovakia with $90 \%$ confidence interval

\begin{tabular}{c|ccc}
\hline Period & Forecast & Upper 90.0\% limit & Lower 90.0\% Limit \\
\hline 2016 & 10.08 & 10.80 & 9.36 \\
2017 & 11.41 & 12.47 & 10.34 \\
2018 & 12.86 & 14.36 & 11.36 \\
2019 & 14.47 & 16.45 & 12.49 \\
2020 & 16.25 & 18.53 & 13.98 \\
\hline
\end{tabular}

Source: Authors' own research. 
Table 2 shows forecast ex ante for the contribution of the RES on gross inland energy consumption in \% in Slovakia, including $90 \%$ confidence interval. According the model the share of the RES should increase and in 2020 might stand around the $16.25 \%$ level.

Regarding the Theil decomposition of the mean square error (MSE) we have found out the following results: $1=U_{m}+U_{R}+U_{D}=0.041+0.212+0.746$.

This means that according to the literature source the largest deviation of the model was caused by the non-systematic error, which is positive. The mean absolute percentage error is relatively high, becomes $37 \%$.

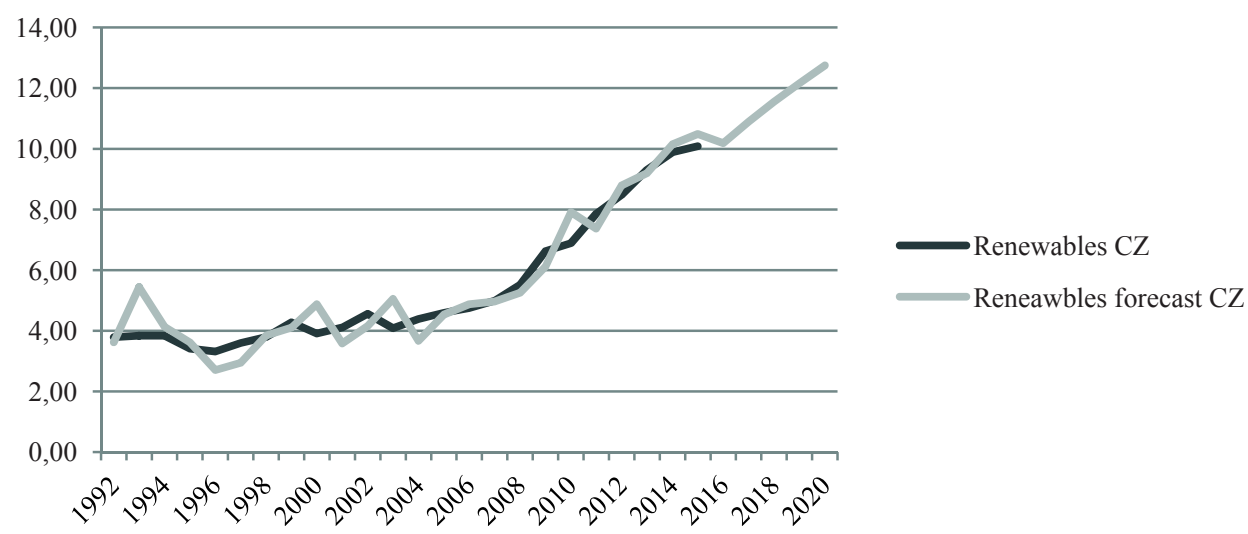

Fig. 2. Extrapolation of the trend of the contribution of the RES on gross inland energy consumption in Czech Republic in \%

Sources: Authors' own research, based on Eurostat data, 2017.

In Figure 2 we can observe the potential development of the RES on gross inland energy consumption till 2020 in the Czech Republic. After some stagnation during the years $1992-2004$, we might observe relatively steady rising trend of share of use of the RES on energy consumption. According to the model we might expect to fulfil national object of reaching $13.5 \%$ of the share of RES on energy consumption till 2020.

Table 3. Forecast ex ante for the share of the RES on gross inland energy consumption in the Czech Republic with $90 \%$ confidence interval

\begin{tabular}{c|ccc}
\hline Period & Forecast & Upper 90.0\% limit & Lower 90.0\% Limit \\
\hline 2016 & 10.19 & 11.31 & 9.06 \\
2017 & 10.89 & 12.46 & 9.33 \\
2018 & 11.56 & 13.58 & 9.53 \\
2019 & 12.15 & 14.65 & 9.66 \\
2020 & 12.75 & 15.06 & 10.44 \\
\hline
\end{tabular}

Source: Authors' own research.

Table 3 shows forecast ex ante for the contribution of the RES on gross inland energy consumption in \% in the Czech Republic, including 90\% confidence interval. According the model the share of the RES should increase and in 2020 might stand around the $12.75 \%$ level. 
Regarding the Theil decomposition of the mean square error (MSE) we have found out the following results: $1=U_{m}+U_{R}+U_{D}=0.0346+0.014+0.981$.

The largest deviation of the model was overwhelmingly caused by the non-systematic error, which is positive. The mean absolute percentage error is relatively low, becomes $8.4 \%$.

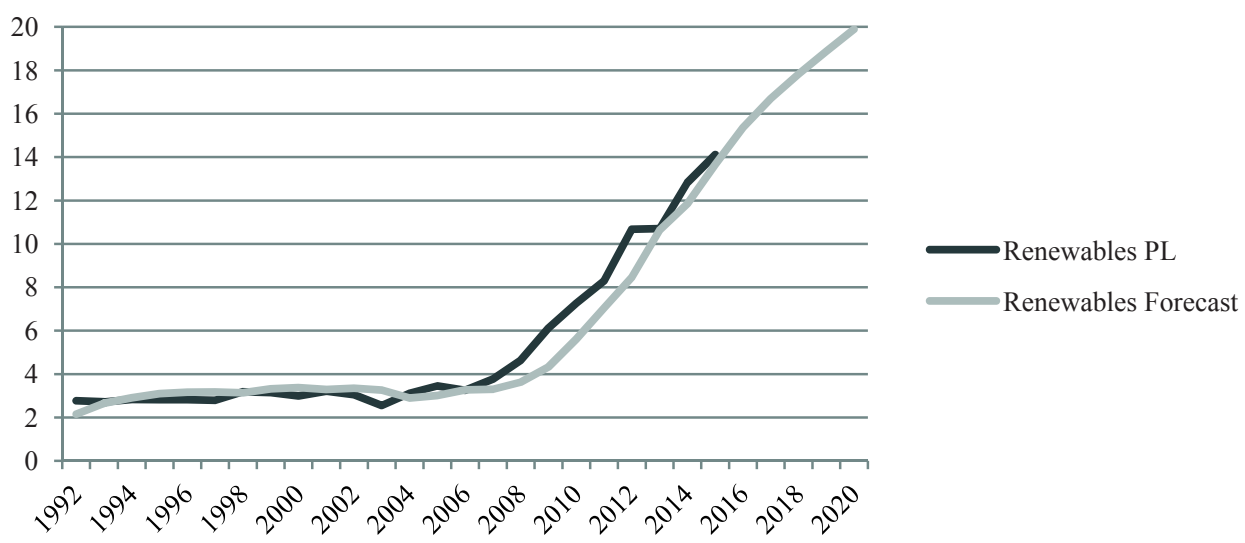

Fig. 3. Extrapolation of the trend of the contribution of the RES in gross inland energy consumption in Poland in $\%$

Sources: Authors' own analysis, based on Eurostat data, 2017.

In Figure 3 we can observe the potential development of the RES on gross inland energy consumption till 2020 in Poland. After some stagnation period during the years 1992 - 2008, trend had picked up and we might observe the steady rising trend of share of the use of the RES on energy consumption. According the model we might expect to exceed national object of reaching $15.5 \%$ of the share of RES on energy consumption till 2020.

Table 4. Forecast ex ante for the share of the RES on gross inland energy consumption in Poland with $90 \%$ confidence interval

\begin{tabular}{c|ccc}
\hline Period & Forecast & Upper 90.0\% limit & Lower 90.0\% Limit \\
\hline 2016 & 15.36 & 16.54 & 14.17 \\
2017 & 16.69 & 18.41 & 14.98 \\
2018 & 17.83 & 20.09 & 15.57 \\
2019 & 18.87 & 21.65 & 16.10 \\
2020 & 19.90 & 23.37 & 16.42 \\
\hline
\end{tabular}

Source: Authors' own research.

Table 4 shows forecast ex ante for the contribution of the RES on gross inland energy consumption in \% in Poland, including 90\% confidence interval. According the model the share of the RES should increase and in 2020 might stand around the $19.9 \%$ level.

Regarding the Theil decomposition of the mean square error (MSE) we have found out the following results: $1=U_{m}+U_{R}+U_{D}=0.044+0.071+0.884$.

In this case again, the largest deviation of the model was caused by the non-systematic error, which is positive. The mean absolute percentage error is relatively low, becomes $21 \%$. 


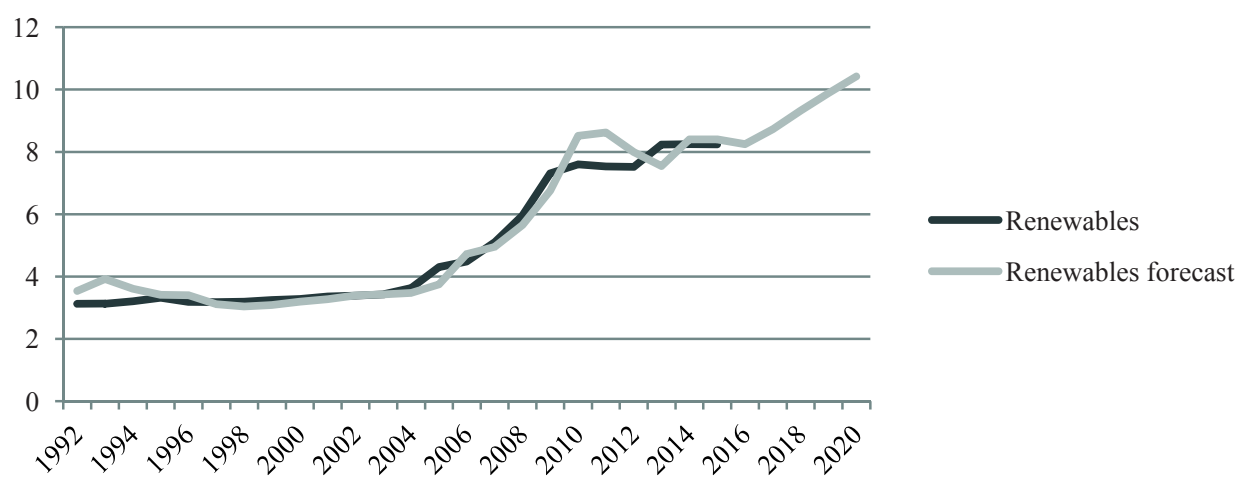

Fig. 4. Extrapolation of the trend of the contribution of the RES in gross inland energy consumption in Hungary in $\%$

Sources: Authors' own processing, based on Eurostat data, 2017.

In Figure 4 we can observe the potential development of the RES on gross inland energy consumption till 2020 in Hungary. After a stagnation period during the years 1992 2004, trend had picked up and we might observe the steady rising trend with a possible cycle indication in 2010/2012, however we neglect it. According the model we might expect to fail to reach national object of $14.65 \%$ of the share of RES on energy consumption till 2020.

Table 5. Forecast ex ante for the share of the RES on gross inland energy consumption in Hungary with $90 \%$ confidence interval

\begin{tabular}{c|ccc}
\hline Period & Forecast & Upper 90.0\% limit & Lower 90.0\% Limit \\
\hline 2016 & 8.25 & 8.95 & 7.54 \\
2017 & 8.73 & 9.72 & 7.75 \\
2018 & 9.32 & 10.59 & 8.06 \\
2019 & 9.89 & 11.40 & 8.38 \\
2020 & 10.42 & 11.98 & 8.87 \\
\hline
\end{tabular}

Source: Own research.

Table 5 shows forecast ex ante for the contribution of the RES on gross inland energy consumption in \% in Hungary, including $90 \%$ confidence interval. According the model the share of the RES should increase and in 2020 might stand around the $10.42 \%$ level.

Regarding the Theil decomposition of the mean square error (MSE) we have found out the following results: $1=U_{m}+U_{R}+U_{D}=0.008+0.003+0.988$

The largest deviation of the model was caused by the non-systematic error, which is positive. The mean absolute percentage error is relatively low, becomes $1.4 \%$. 


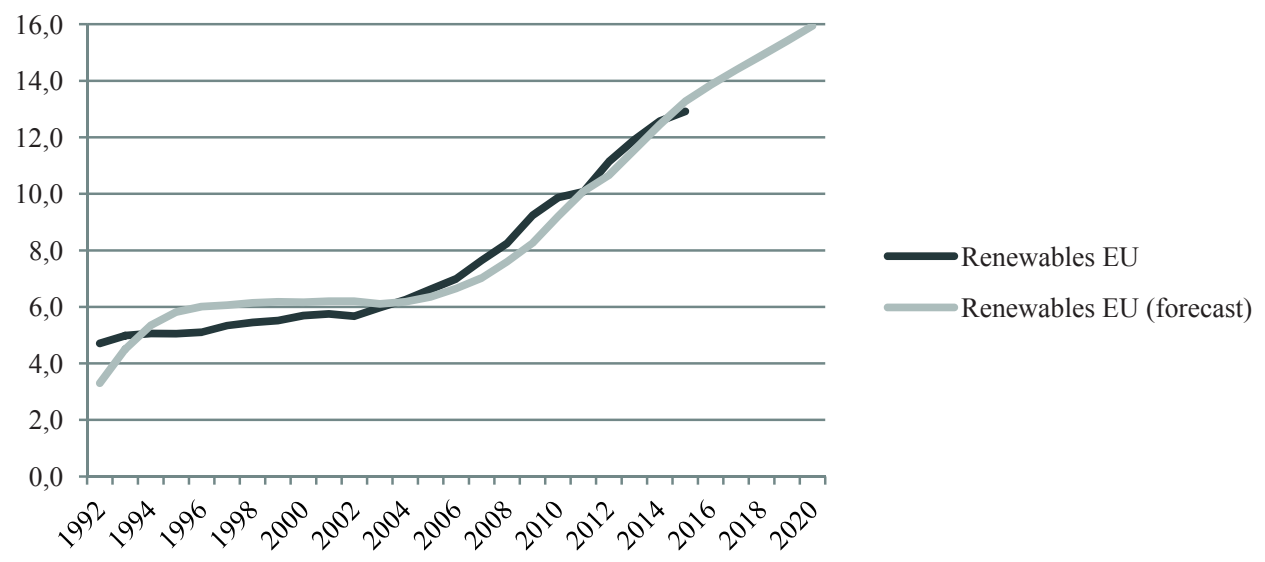

Fig. 5. Extrapolation of the trend of the contribution of the RES in gross inland energy consumption in EU-28 (in average) in \%

Sources: Authors' own analysis, based on Eurostat data, 2017.

In Figure 5 we can observe the potential development of the RES on gross inland energy consumption till 2020 in EU-28. After a moderate growth during the years $1992-$ 2005 , trend had taken up an upward direction and we might observe the steady rising trend in the share of RES on energy consumption in all member states of EU-28. However we might expect to fail to reach common EU object of $20 \%$ of the share of RES on energy consumption till 2020.

Table 6 shows forecast ex ante for the contribution of the RES on gross inland energy consumption in \% in EU-28, including 90\% confidence interval. According the model the share of the RES should increase and in 2020 might stand around the $15.94 \%$ level.

Table 6. Forecast ex ante for the share of the RES on gross inland energy consumption in Eu-28 with $90 \%$ confidence interval

\begin{tabular}{c|ccc}
\hline Period & Forecast & Upper 90.0\% limit & Lower 90.0\% Limit \\
\hline 2016 & 13.86 & 14.87 & 12.84 \\
2017 & 14.39 & 15.81 & 12.96 \\
2018 & 14.90 & 16.76 & 13.04 \\
2019 & 15.41 & 17.69 & 13.13 \\
2020 & 15.94 & 18.80 & 13.08 \\
\hline
\end{tabular}

Source: Authors' own research.

Regarding the Theil decomposition of the mean square error (MSE) we have found out the following results: $1=U_{m}+U_{R}+U_{D}=0.006+0.016+0.977$.

The largest deviation of the model was caused by the non-systematic error, which is positive. The mean absolute percentage error is relatively low, becomes $7.2 \%$. 


\section{Conclusions}

The aim of the paper was to point on the use of forecasting model for extrapolating the trend of ex ante, based on time series of development of the RES on gross inland energy consumption for the V4 and EU-28 countries, and give an overview of legislation on the EU and the national level. For this purpose we opted to use of the Brown triple exponential smoothing model, which takes into account seasonal changes as well as trends. For approximation trend, as well as forecast ex-ante, we have taken the second-order polynomial model. The estimation was based on time series observation between the respective years of 1992-2015, with extrapolation of the trend up to 2020.

In despite of limited possibilities of the model to make an accurate prognosis up to 2020 we came to the conclusion, that Slovakia, the Czech Republic and Poland, might fill its national objective of the share of RES on gross energy consumption till 2020. In case of Hungary and the EU-28, they might fail short of filling their objectives on share of RES on gross energy consumption till 2020.

It is an interesting fact, that Hungary, which is by our prognosis the only country from V4 countries, that is likely to fail its 2020 objectives, is also the only country from V4 countries that does not have a general law on RES. On the other hand, it must be also stated, that even though 3 out of 4 comparing countries of V4 by our prognosis are likely to fulfil their 2020 objectives; all four countries of V4 are below average of sustainability for environment and energy. All four V4 countries are way below the EU-28 average in recycling and government expenditures for environmental protection actions and below or really slightly above EU-28 average in gross share RES energy in all three fields, electricity, transportation and heating and cooling (Cucchiella, D'Adamo, Gastaldi, Koh, Rosa, 2017).

Moreover, the model odes not"perfectly" fit to the measured data, in each case, making possible forecast more confident. For instance, in case of Slovakia and Poland the mean absolute percentage error is relatively high, as it amounts to $37 \%$ and $19.19 \%$ respectively, also $U_{R}$ parameters suggest greater deviation of the population regression function from the measured data, especially in the case of Slovakia. Thus it points on the possible weaknesses of the model, however in the case of other V4 countries and also the EU-28, the deviations in parameters became minimal.

In the paper we have been dealing only with the prognostic application of the model and thus we have relaxed some assumptions like possible residual autocorrelation, which might be expected. Moreover, the model is able, with some level of the confidence, to make prognosis only on such a short time periods ex ante (best $h=1$ ). In case of our model, for the purpose of making the estimation of the parameters, we made before the estimation of the observing values $y_{t+n}=1,2 \ldots n$ based on the average coefficient of the growth of the variable, which might be unrealistic in real conditions. However, the prognostic applications are always connected with distortion and uncertainty, but have practical value in terms of the planning and adjusting the condition in order to achieve the desired results.

\section{References}

A policy framework for climate and energy in the period from 2020 to 2030. (2014).

Bowerman, B.L., O’Connel, R.T. (2007). Time Series Forecasting, 1987, In: Rublíková, E., Analýza časových radov, Prvé vydanie. Iura Edition. 
Cucchiella, F., D'Adamo, I., Gastaldi, M., Koh, S.L., Rosa, P. (2017). A comparison of environmental and energetic performance of European countries: A sustainability index. Renewable and Sustainable Energy Reviews, 78, 401-413.

de Llano-Paz, F., Martínez Fernandez, P., Soares, I. (2016). Addressing 2030 EU policy framework for energy and climate: Cost, risk and energy security issues. Energy, 115, 1347-1360.

Liobikienè, G., Butkus, M. (2017). The European Union possibilities to achieve targets of Europe 2020 and Paris agreement climate policy. Renewable Energy, 106, 298-309.

Giacomarra, M., Bono, F. (2015). European Union commitment towards RES market penetration: From the first legislative acts to the publication of the recent guidelines on State aid 2014/2020. Renewable and Sustainable Energy Reviews, 47, 218-232.

Hamilton, J.D. (1994). Time Series Analysis, First Edition. Princeton University press.

Klessmann, C., Held, A., Rathmann, M., Ragwitz, M. (2011). Status and perspectives of renewable energy policy and deployment in the European Union - What is needed to reach the 2020 targets? Energy Policy, 39(12), 7637-7657.

Neusser, K. (2015). Time Series Analysis in Economics. Available at: http://www.neusser.ch/downloads/Time SeriesBook.pdf.

Proskurina, S., Sikkema, R., Heinimö, J., Vakkilainen, E. (2016). Five years left - How are the EU member states contributing to the $20 \%$ target for EU's renewable energy consumption; the role of woody biomass. Biomass and Bioenergy, 95, 64-77.

RES LEGAL Europe - legal sources on renewable energy. Available 23.10.2017 at: http://www.res-legal.eu/ compare-support-schemes/.

Rublíková, E. (2007). Analýza časových radov (Time Series Analysis). Prvé vydanie. Iura Edition.

Strunz, S., Gawel, E., Lehmann, P. (2016). The political economy of renewable energy policies in Germany and the EU. Utilities Policy, 42, 33-41.

The Energy Policy of the Slovak Republic. 2014.

\section{For citation:}

Marišová E., Mariš M., Gaduš J., Parlińska A. (2018). Legal Regulations and the Perspectives of Renewable Energy Policy in Selected EU Member States. Problems of World Agriculture, 18(3), 216-228; DOI: 10.22630/PRS.2018.18.3.80 